\title{
İktisadi Hoşnutsuzluk Endeksi ve Terörizm Arasındaki İlişki: Türkiye ve Avrasya Ülkeleri Örneği
}

Öz

\author{
Rabia EFEOĞLU*
}

Çalışmada Türkiye ve Avrasya ülkelerinde 2002-2018 yılları arasında terör olaylarının iktisadi hoşnutsuzluk endeksi üzerindeki etkisi analiz edilmiştir. Analizde yatay kesit bağımlılığı ve heterojenliği dikkate alan ikinci nesil panel veri analiz yöntemleri kullanılmıştır. Öncelikle modelde yatay kesit bağımlılığının olup olmadığı incelenmiştir. Akabinde CADF birim kök testiyle serilerin durağanlı̆̆ araştırılmış, daha sonra homojenlik testi uygulanmıştır. Westerlund (2007) bootstrap panel eşbütünleşme testiyle değişkenler arasındaki uzun dönemli ilişki analiz edilmiştir. Bootstrap panel eşbütünleşme testi sonucunda, Türkiye ve Avrasya ülkelerinde terör olayları ile iktisadi hoşnutsuzluk endeksi arasında eşbütünleşme ilişsisi olduğu sonucuna varılmıştır. Panelin genelinde terör olaylarındaki artıș iktisadi hoșnutsuzluğu artırmaktadır. Ülkeler bazında elde edilen bulgulara göre ise, Azerbaycan, Belarus, Gürcistan, Rusya, Ukrayna ve Türkiye'de terörün iktisadi hoşnutsuzluk endeksi üzerindeki etkisi pozitif (terör olaylarındaki artış iktisadi hoşnutsuzluğu artırmakta); Ermenistan, Kırgızistan ve Moldova'da negatiftir (terör olaylarındaki artı̧̧ iktisadi hoşnutsuzluğu azaltmakta). Ancak Azerbaycan, Ukrayna ve Moldova'da istatistiksel olarak anlamsız bir ilișki bulunmuștur. Son olarak Dumitrescu-Hurlin Granger panel nedensellik testi uygulanmış ve test sonucunda terör olaylarından iktisadi hoşnutsuzluk endeksine doğru tek yönlü nedensellik ilişkisi olduğu görülmüş̧ür. Bu çerçevede Türkiye ve Avrasya ülkelerinde terör olaylarındaki artışın iktisadi hoşnutsuzluğu artırdığı söylenebilmektedir. Dolayısıyla Türkiye ve Avrasya ülkelerinde sosyal bir hoşnutsuzluk göstergesi olan terör olaylarının sebep olduğu ve artırdığı iktisadi hoşnutsuzluğu azaltabilmek amacıyla, terörizmin söz konusu ülkelere yüklemiş olduğu makroekonomik maliyetler tespit edilebilirse bu durum söz konusu ülkelerde sorunun çözümünde yol gösterici olabileceği şeklinde bir politika önerisinde bulunulabilir. Anahtar Kelimeler: İktisadi Hoşnutsuzluk Endeksi, Terörizm, Panel Veri Analizi

\section{The Relationship Between Misery Index and Terrorism: Evidence From Turkey and Eurasian Countries}

\begin{abstract}
In study, the impact of terrorist incidents on misery index were analyzed between 2002-2018 in Turkey and Eurasian countries. In the analysis, second generation panel data analysis methods that take into account cross sectional dependency and heterogeneity were used. Firstly, it was investigated whether there is cross sectional dependency in the model. Subsequently, the stationarity of the series was investigated with the CADF unit root test, then the homogeneity test was applied. The long-term relationship between the variables was analyzed by Westerlund (2007) bootstrap panel cointegration test. In the bootstrap panel cointegration test results, it was concluded that there is cointegration relationship between the terrorist incidents and misery index in Turkey and Eurasian countries. The increase in terrorist incidents throughout the panel increases misery index. According to the findings obtained on the basis of countries, the effect of terrorism on the misery index is positive in Azerbaijan, Belarus, Georgia, Russia, Ukraine and Turkey (the increase in terrorist incidents increases misery index); it is negative in Armenia, Kyrgyzstan and Moldova (the increase in terrorist incidents reduces misery index). However, a statistically insignificant relationship was found in Azerbaijan, Ukraine and Moldova. Later, Dumitrescu-Hurlin Granger panel causality test was applied and the test result showed that there is a one-way causality relationship from terrorist incidents to economic discontent index. In this context, it can be said that the increase in terrorist incidents increased the misery index in Turkey and Eurasian countries. Therefore, in order to reduce the misery index caused and increased by terrorist incidents, which are a social discontent indicator in Turkey and Eurasian countries, a policy proposal can be made that if the macroeconomic costs of terrorism on the said countries can be determined, this situation can guide the solution of the problem in these countries.
\end{abstract}

Keywords: Misery Index, Terrorism, Panel Data Analysis

Geliş/Received: 03.02.2021

Kabul/Accepted: 25.06 .2021

* Bu çalışma, insanlardan veri ve örnek toplamayı gerektiren, anket, inceleme, alan çalışması ve deney içeren araştırmalar kapsamına girmediğinden etik kurul onay belgesi gerektirmemektedir.

\footnotetext{
* Dr. Öğr. Üyesi, Kastamonu Üniversitesi, İktisadi ve İdari Bilimler Fakültesi, Finans ve Bankacıllk Bölümü, refeoglu@kastamonu.edu.tr, ORCID: 0000-0003-2515-1553

(Makale türü: Araştırma makalesi)
} 


\section{Giriş}

Sefalet endeksi olarak da adlandırılan iktisadi hoşnutsuzluk endeksi ilk olarak Arthur Okun tarafından 1970'li yıllarda ortaya atılmıştır. Okun söz konusu endeksi enflasyon oranı ve işsizlik oranının toplamından elde etmiştir. Şüphesiz ki enflasyon ve işsizlik bir ekonominin temel makroekonomik belirleyicilerindendir. Enflasyon oranı ve işsizlik oranında meydana gelen artışlar sırasıyla satın alma gücü ve istihdam düzeyinin azalmasını ifade ettiğinden bu durumda makroekonomik performansın kötüleştiği söylenebilir ki, söz konusu durum iktisadi hoşnutsuzluğun arttığının bir göstergesidir. Ülkelerin enflasyon ve işsizlik oranları hakkında bilgi veren, makroekonomik performansın yanı sıra toplumun yaşam memnuniyetini de ölçmekte kullanılan iktisadi hoşnutsuzluk endeksinin yükselmesi artan hoşnutsuzluğu, düşmesi azalan hoşnutsuzluğu göstermektedir.

Hoşnutsuzluk endeksi kapsamında ekonomik hoşnutsuzluk endeksi parametrelerinin yanı sıra sosyal hoşnutsuzluk endeksi parametrelerinin de yer aldığı söylenebilir. Toplumlarda iktisadi olayların sosyal hayata yansıması veya sosyal hayatın iktisadi olaylara yansıması olabilmekte, ülkelerin ekonomik ve sosyal yaşantıları birbirini etkileyebilmektedir. Bu kapsamda ülkelerin iktisadi hoşnutsuzluk ile sosyal hoşnutsuzlukları arasında bir neden-sonuç ilişkisinin kurulması mümkün görünmektedir. İktisadi hoşnutsuzluk göstergeleri enflasyon ve işsizlik oranlarından oluşurken, sosyal hoşnutsuzluk göstergeleri göç, boşanma, intihar, suç oranları, terör eylemleri, devlet ve siyasal sisteme olan güvenin yıpranması şeklinde sıralanabilir.

Hoşnutsuzluk endeksindeki ekonomik hoşnutsuzluk parametreleri ve sosyal hoşnutsuzluk parametreleri kavramsal olarak şu şekilde açılanabilir. İktisadi hoşnutsuzluk göstergelerinden enflasyon, belirli bir dönemde fiyatlar genel düzeyindeki artış olarak tanımlanmaktadır. Okun İktisadi Hoşnutsuzluk Endeksinin hesaplanmasında kullanılan enflasyon değişkeni tüketici fiyatlarındaki yıllık yüzde değişimdir. Buna göre tüketici fiyatlarındaki artış, halkın alım gücünü düşürerek hane halkı reel gelir ve refahının düşmesine sebep olmaktadır. Okun İktisadi Hoşnutsuzluk Endeksinin hesaplanmasında kullanılan diğer bir gösterge işsizlik oranıdır. İşsizlik, cari ücret düzeyinde çalışmaya razı olunmasına rağmen iş bulunamaması durumudur. İşsizlik oranı ise işsiz nüfusun işgücüne oranıdır. Okun endeksinde işgücünün yıllık yüzdesi işsizlik oranını temsil etmektedir. İşsizliğin artışı yoksulluk düzeyini artırarak yine hane halkı gelirlerinde düşüşe ve refah kaybına neden olmaktadır. Dolayısıyla makroekonomik açıdan enflasyon ve işsizliğin artışı birleşince gelirin satın alma gücü azalmakta, reel kesimin yatırım kararları olumsuz yönde etkilenmekte, bunun sonucunda da refah kaybı ortaya çıkmaktadır.

Sosyal hoşnutsuzluk göstergelerinden göç; iktisadi, sosyal, siyasal, dini gibi nedenlerle bireylerin ya da toplulukların bulundukları, oturdukları yerleşim yerini bırakarak başka bir yerleşim yerine ya da başka bir ülkeye gitmek suretiyle yaptıkları coğrafi yer değiştirme hareketidir. Göç, hem göç edilen bölgenin hem de terk edilen bölgenin ekonomik ve sosyal yapısını değiştirmektedir. Genel olarak az gelişmiş il, bölge ve ülkelerden gelişmiş il, bölge ve ülkelere nüfus hareketleri fazladır. Bu 
nedenle nüfusun net göç ile ilgili bilgileri ülkelerin ekonomik görünümleri hakkında bilgi vericidir. Net göç, nüfus hareketlerini açılayan önemli bir göstergedir ve alınan göç ile verilen göç arasındaki farkı ifade eder. Ülkenin dışarıya göç vermesi negatif net göç hızı, dışarıdan göç alması pozitif net göç hızıdır (Taşcı ve Özsan, 2011: 3). Göçün nedenleri arasında iktisadi yapıdaki dönüşümler, teknolojideki gelişmeler, istihdam, sağlık ve eğitim imkânları, terör olayları, güvenlik sorunları sayılabilir. Ülkeden ülkeye hatta toplum yapısındaki değişime bağlı olarak hızı farklılaşan sosyal hoşnutsuzluk göstergelerinden olan boşanma evliliğin bitirilmesidir. Boşanmanın genel nedenleri; şiddetli geçimsizlik, maddi sıkıntılar, zina, kısırlık, ruh ve beden hastalığı, içki, kumar, kötü muamele, evi terk etme, cana kast, akrabaların karışmasıdır. Sosyal hoşnutsuzluk göstergelerinden intihar, kişinin psikolojik ve toplumsal sebeplerle kendi hayatına son vermesidir. En temel intihar sebepleri yoksulluk, hastalık, geçim zorluğu, aile içi geçimsizlik olarak sayılabilir. Sosyal hoşnutsuzluk göstergelerinden suç, "topluma zarar verdiği ya da tehlikeli olduğu kanun koyucu tarafindan kabul edilen ve belirtilen eylem, davranış, tavır ve harekettir" (Taşcı ve Özsan, 2011: 6). Suç sosyal yapıya zarar vererek toplumsal bütünlüğü bozup toplumda dayanışma ve yardımlaşma bağlarını koparır. Suç oranlarının artmasında kentleşme, göç, nüfus artışı, gelir eşitsizliği, alkol ve uyuşturucu alışkanlığının gelişmesi, işsizlik, aile kurumunun zayıflaması, geleneksel değer ve bağlılıkların zayıflaması, kültürel farklılığın ve çatışmanın artması gibi nedenler etkilidir (Çondur, 2016: 1315). Sosyal hoşnutsuzluk göstergelerinden devlet ve siyasal sisteme olan güvenin yıpranması, siyasal sisteme ilgi azalışını ifade etmektedir. Daha çok kırsal kesimlerde görülen bu durumdan ekonomik, sosyal ve kültürel seviyeleri düşük olan vatandaşların daha çabuk etkilenmesi söz konusudur. Sosyal hoşnutsuzluk göstergelerinden terör eylemleri, iktisadi, siyasi, sosyal ve kültürel alanlarda ortaya çıkan önemli bir sorundur. Böyle bir sorunun ortaya çıkmasında teröristlerin kişisel dünyalarındaki sorunları ile insanların yaşadıkları sorunlar dolayısıyla teröre yönelmeleri söz konusudur. Özellikle ekonomik ve sosyal bakımdan boşluk içinde olmaları onları bu yola yönlendiren sebeplerdendir. Buradan hareketle sosyal hoşnutsuzluk göstergelerinin makroekonomik sorunlar özelinde iktisadi hoşnutsuzluk ile ilişkili olduğu söylenebilir. Genel anlamda iktisadi hoşnutsuzluğun arttığı yerde sosyal hoşnutsuzluğun da artması mümkün iken, sosyal hoşnutsuzluğun arttığı yerde iktisadi hoşnutsuzluğun artması da mümkündür.

Çalışmanın konusu kapsamında iktisadi hoşnutsuzluk ve sosyal hoşnutsuzluk göstergelerinden terör olayları arasındaki ilişki incelendiğinde; terör eylemlerinin sosyal, siyasal, psikolojik sonuçlarının yanı sıra ekonomik sonuçları da söz konusudur. Terör eylemlerinin ekonomik sonuçları kısa ve uzun vadede kendini göstermektedir. Terörün ekonomiye etkisi bakımından; can kayıpları, zarar gören altyapı tesislerinin onarımı ve yapımı gibi terörün doğrudan ekonomik maliyetlerinin hemen ortaya çıktığı, tüketici ve yatırımcılar üzerinde yarattı̆̆ güvensizlik gibi dolaylı ekonomik maliyetlerinin ise ülkelere, sektörlere ve zamana göre farkl1lık gösterebildiği söylenebilmektedir (Korkmaz, 2018: 76). Diğer bir ifadeyle terör-ekonomi özelinde terör ile iktisadi hoşnutsuzluk endeksi arasındaki ilişki 


\section{Rabia EFEOĞLU}

İktisadi Hoşnutsuzluk Endeksi ve Terörizm Arasındaki İlişki: Türkiye ve Avrasya Ülkeleri Örneği

bakımından terör faaliyetlerinin artmasının faizleri artırması ve akabinde yatırımları engellemesi, reel geliri ve ekonomik büyümeyi düşürmesi, ülkeye yabancı sermaye girişini sınırlandırması gibi sebeplerle ülkelerdeki işsizlik ve enflasyon üzerinde olumsuz bir etki yaratması muhtemeldir. Ayrıca enflasyon ve işsizlik oranlarının artmasının da terörü teşvik etme ihtimali olasıdır.

Çalışmada ele alınacak olan Türkiye ve Avrasya ülkelerinde iktisadi hoşnutsuzluk ve terör olaylarının gelişimi incelendiğinde; 2002-2018 döneminde enflasyonun en yüksek olduğu ülke Belarus, işsizliğin en yüksek olduğu ülke Gürcistan'dır. Söz konusu yıllar arasında iktisadi hoşnutsuzluğun en yüksek olduğu ülke Belarus, terör olaylarının en yüksek olduğu ülke ise Türkiye'dir. 2018 yılına gelindiğinde ise, Ermenistan en yüksek işsizliğe, Türkiye en yüksek enflasyona, en yüksek iktisadi hoşnutsuzluk endeksine ve en yüksek terör olaylarına sahip ülke olmuştur.

Buradan hareketle çalışmada Türkiye ve Avrasya ülkelerinde iktisadi hoşnutsuzluk endeksi ile sosyal hoşnutsuzluk göstergesi olan terör olayları arasındaki ilişki analiz edilmektedir. Literatürde iktisadi hoşnutsuzluk endeksi üzerine yapılan çalışmalar olmakla birlikte çoğunlukla diğer makroekonomik göstergeler ile ilişkisine değinilmiş, sosyal boyut ile ilişkisi az sayıda çalışılarak ihmal edilmiştir. Bu kapsamda çalışmada iktisadi hoşnutsuzluk endeksi ile sosyal hoşnutsuzluk göstergesi olan terör olayları arasındaki ilişkinin incelenmesi gereği duyulmuştur. Böylece sosyal hoşnutsuzluk göstergesi olarak terör olayları kullanılmış ve aralarındaki ilişki irdelenmiştir. Literatürde sosyal boyut anlamında iktisadi hoşnutsuzluk ile diğer sosyal göstergeler arasında ilişki araştırılmış olsa da terör eylemleri ile ilişkisinin araştıııldığı çalışmalara rastlanılmamıştır. $\mathrm{Bu}$ yönüyle çalışma diğer çalışmalardan farklılık göstermektedir. Ayrıca iktisadi hoşnutsuzluk literatüründe Avrasya ülkeleri özelinde de herhangi bir çalışmaya rastlanılmaması çalışmanın diğer bir ayırıcı özelliğidir. Bu durum Türkiye ile birlikte Avrasya ülkelerinin çalışmada örneklem olarak seçilme sebebidir. Ayrıca yoğun terör olaylarına maruz kalan ülkelerin ekonomik olarak istikrarsız bir yapıya sahip olduğu düşüncesinden hareketle, Sovyetler Birliği'nin (SSCB) dağılmasından sonra kurulan Avrasya ülkelerinde terör olaylarına maruz kalma durumları ve Türkiye'nin tarihsel süreç içerisinde devamlı terörle mücadelesi göz önünde bulundurularak söz konusu ülkelerin incelenmesi önem arz etmiştir. Çalışmanın giriş bölümünü izleyen bölümlerde sırasıyla iktisadi hoşnutsuzluk endeksi literatürü üzerinde durulmakta, veri seti tanıtılmakta, metodoloji ve analiz bulgularına yer verilmekte ve sonuç bölümü ile çalışma tamamlanmaktadır.

\section{Literatür Özeti}

İktisadi hoşnutsuzluk endeksi literatürü incelendiğinde iktisadi hoşnutsuzluğun gerek makroekonomik göstergelerle gerekse de sosyal göstergelerle ilişkisinin araştırıldığı çalışmaların sınırlı olduğu görülmektedir. Her bir çalışmanın ülke, yöntem, dönem bakımından farklılık gösterdiği çalışmalarda sonuçların da birbirinden farklılık gösterdiği görülmektedir. Tablo 1'de konu ile ilgili literatür özeti sunulmuştur.

Tablo 1: İktisadi Hoşnutsuzluk Literatür Özeti 


\begin{tabular}{|c|c|c|c|}
\hline Yazar/Yıl & Ülke/Dönem & Yöntem & Sonuç \\
\hline $\begin{array}{l}\text { Lee ve } \\
\text { diğerleri } \\
\text { (2007) }\end{array}$ & $\begin{array}{l}\text { ABD, Japonya, } \\
\text { Kore/1967-2001 }\end{array}$ & $\begin{array}{l}\text { Temel } \\
\text { analizi }\end{array}$ & $\begin{array}{l}\text { Düşük iktisadi hoşnutsuzluk yüksek ekonomik } \\
\text { performans ile ilişkilidir. }\end{array}$ \\
\hline $\begin{array}{l}\text { Welsch } \\
(2007)\end{array}$ & $\begin{array}{l}12 \quad \text { Avrupa } \\
\text { Ülkesi/1992-2002 }\end{array}$ & Regresyon analizi & $\begin{array}{l}\text { Okun hoşnutsuzluk endeksine göre, iktisadi } \\
\text { hoşnutsuzluk arttıça yaşam memnuniyeti } \\
\text { azalmakta, Barro hoşnutsuzluk endeksine göre, } \\
\text { iktisadi hoşnutsuzluk ve yaşam memnuniyeti } \\
\text { arasında bir ilişki yoktur. }\end{array}$ \\
\hline $\begin{array}{l}\text { Lechman } \\
(2009)\end{array}$ & $\begin{array}{l}27 \text { AB Ülkesi/2001- } \\
2007\end{array}$ & Korelasyon analizi & $\begin{array}{l}\text { Okun hoşnutsuzluk endeksi ve Barro } \\
\text { hoşnutsuzluk endeksine göre, iktisadi } \\
\text { hoşnutsuzluk endeksi ve yoksulluk oran } \\
\text { arasında herhangi bir ilişki yoktur. }\end{array}$ \\
\hline $\begin{array}{l}\text { Grabia } \\
(2012)\end{array}$ & $\begin{array}{l}27 \text { AB Ülkesi/2000- } \\
2009\end{array}$ & Teorik çalışma & $\begin{array}{l}\text { İktisadi hoşnutsuzluk yüksek gelirli ülkelerde } \\
\text { düşük, düşük gelirli ülkelerde yüksektir. }\end{array}$ \\
\hline $\begin{array}{ll}\text { Dadgar } & \text { ve } \\
\text { Nazari } & \\
\text { (2012) } & \end{array}$ & İran/1974-2011 & $\begin{array}{l}\text { Eşbütünleşme ve } \\
\text { Granger Nedensellik }\end{array}$ & $\begin{array}{l}\text { Dışa açılklk ve anti demokratik gelenek iktisadi } \\
\text { hoşnutsuzluğu artırmakta, ekonomik büyüme } \\
\text { ve insan haklarına saygıll yönetim iktisadi } \\
\text { hoşnutsuzluğu azaltmaktadır. İyi yönetişim } \\
\text { kötüleştikçe iktisadi hoşnutsuzluk artmaktadır. }\end{array}$ \\
\hline $\begin{array}{l}\text { Beşkaya } \\
(2013)\end{array}$ & Türkiye/1980-2010 & $\begin{array}{l}\text { Engle ve Granger } \\
\text { eşbütünleşme }\end{array}$ & $\begin{array}{l}\text { Dışa açıklık, gelir eşitsizliği, demokrasi, faiz } \\
\text { oranı, büyüme arttıça iktisadi hoşnutsuzluk } \\
\text { artmakta, yolsuzluk arttıkça iktisadi } \\
\text { hoşnutsuzluk azalmaktadır. }\end{array}$ \\
\hline $\begin{array}{l}\text { Sadeghi ve } \\
\text { diğerleri } \\
\text { (2014) }\end{array}$ & İran/1972-2011 & STAR modelleri & $\begin{array}{l}\text { İktisadi hoşnutsuzluğun belli bir eşik değeri } \\
\text { geçmesi halinde endeksteki artış gelir } \\
\text { eşitsizliğini artırmaktadır. }\end{array}$ \\
\hline $\begin{array}{l}\text { Çondur } \\
(2016)\end{array}$ & Türkiye/2007-2015 & Teorik çalışma & $\begin{array}{l}\text { Ekonomik hoşnutsuzluk arttıç̧a sosyal } \\
\text { hoşnutsuzluk olumsuz etkilenmektedir. }\end{array}$ \\
\hline $\begin{array}{l}\text { Özcan } \\
(2016)\end{array}$ & $\begin{array}{l}\text { Türkiye ve } 28 \text { AB } \\
\text { Ülkesi/2003-2013 }\end{array}$ & Panel eşbütünleşme & $\begin{array}{l}\text { Okun hoşnutsuzluk endeksine göre iktisadi } \\
\text { hoşnutsuzluktaki artış } \text { yoksulluğu } \\
\text { artırmaktadır. Barro hoşnutsuzluk endeksine } \\
\text { göre, iktisadi hoşnutsuzluk ve yoksulluk } \\
\text { arasinda bir ilişki yoktur. }\end{array}$ \\
\hline $\begin{array}{l}\text { Saboor ve } \\
\text { diğerleri } \\
\text { (2016) }\end{array}$ & Pakistan/1975-2013 & $\begin{array}{l}\text { Granger nedensellik } \\
\text { ve ARDL }\end{array}$ & $\begin{array}{l}\text { Okun hoşnutsuzluk endeksine göre, suç oranı } \\
\text { arttıkça hoşnutsuzluk artmaktadır. Barro } \\
\text { hoşnutsuzluk endeksine göre, iktisadi } \\
\text { hoşnutsuzluk arttıkça suç oranları artmaktadır. }\end{array}$ \\
\hline $\begin{array}{l}\text { Oskay } \\
(2018)\end{array}$ & $\begin{array}{l}\text { Brezilya, Endonezya, } \\
\text { Hindistan, Güney } \\
\text { Afrika, Türkiye/2008 }\end{array}$ & Teorik çalışma & 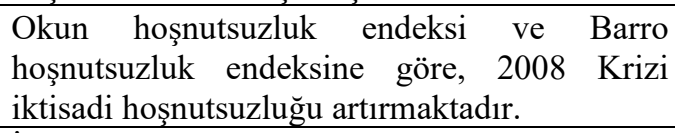 \\
\hline $\begin{array}{l}\text { Özdemir ve } \\
\text { Salihoğlu } \\
\text { (2019) }\end{array}$ & 40 ülke & $\begin{array}{l}\text { En Küçük Kareler } \\
\text { Yöntemi }\end{array}$ & $\begin{array}{l}\text { İktisadi hoşnutsuzluk arttıkça insani gelişme } \\
\text { artmaktadır. }\end{array}$ \\
\hline $\begin{array}{l}\text { Wang ve } \\
\text { diğerleri } \\
\text { (2019) }\end{array}$ & Pakistan/1989-2017 & ARDL & $\begin{array}{l}\text { İktisadi hoşnutsuzluk endeksindeki artış } \\
\text { ekonomik büyümeyi azaltmaktadır. }\end{array}$ \\
\hline $\begin{array}{l}\text { Akay ve } \\
\text { Oskonbaeva } \\
(2020)\end{array}$ & $\begin{array}{l}16 r \text { Geçiş } \\
\text { Ülkesi/1996-2017 }\end{array}$ & Panel ARDL & $\begin{array}{l}\text { Sefalet endeksindeki artış ekonomik büyümeyi } \\
\text { azaltmaktadır. }\end{array}$ \\
\hline $\begin{array}{ll}\text { Ülgen } & \text { ve } \\
\text { Özer } & \\
(2020) & \end{array}$ & Türkiye/2000-2018 & $\begin{array}{l}\text { Fourier } \\
\text { Eşbütünleşme ve } \\
\text { Dinamik En Küçük } \\
\text { Kareler Yöntemi }\end{array}$ & $\begin{array}{l}\text { Okun hoşnutsuzluk endeksi ve Barro } \\
\text { hoşnutsuzluk endeksine göre, cari açık arttıkça } \\
\text { iktisadi hoşnutsuzluk azalmakta, iktisadi } \\
\text { hoşnutsuzluk arttıkça cari açı azalmaktadır. }\end{array}$ \\
\hline
\end{tabular}




\section{Veri Seti}

Çalışmada Türkiye ve 8 Avrasya ülkesi (Ermenistan, Azerbaycan, Belarus, Gürcistan, Kırgızistan, Moldova, Rusya, Ukrayna) olmak üzere 9 ülkede 2002-2018 dönemi y1llık verileri kullanılarak terör olaylarının iktisadi hoşnutsuzluk endeksi üzerine etkisi analiz edilmiştir. Bu çerçevede bağımlı değişken olarak Okun iktisadi hoşnutsuzluk endeksi, bağımsız değişken olarak terör olaylarını temsilen küresel terörizm endeksi kullanılmıştır.

Çalışmada öncelikle paneli oluşturan serilerde yatay kesit bağımlılı̆̆ının olup olmadığı araştırılmıştır. Bunun için Breusch-Pagan (1980) LM testi ile Pesaran ve diğerleri (2008) LMadj $_{\text {ajesti }}$ kullanılmıştır. İkinci aşamada yatay kesit bağımlıı̆̆ını dikkate alan ikinci kuşak birim kök testi olan Pesaran (2007) CADF testi ile birim kök sınaması yapılmıştır. Üçüncü aşamada Swamy S testi ile modelde homojenlik testi gerçekleştirilmiştir. Dördüncü aşamada seriler arasında eşbütünleşme ilişkisinin olup olmadığı Westerlund (2007) bootstrap panel eşbütünleşme testiyle analiz edilmiştir. Beşinci aşamada uzun dönem eşbütünleşme katsayıları tespit edilmiş ve son aşamada Dumitrescu ve Hurlin (2012) panel nedensellik testi ile değişkenler arasındaki nedensellik ilişkisi araştırılmıştır.

Çalışmada terör olaylarının iktisadi hoşnutsuzluk endeksi üzerine etkisini incelemek amacıyla aşağıdaki gibi bir ekonometrik model oluşturulmuştur:

$$
M I_{i t}=\alpha_{i t}+\beta_{1} G T I_{i t}+\mu_{i t}
$$

Modelde; MI Okun iktisadi hoşnutsuzluk endeksini, GTI terör olaylarını temsilen küresel terörizm endeksini ifade etmektedir. İktisadi hoşnutsuzluk endeksine Dünya Bankası, küresel terörizm endeksine Institute for Economics and Peace Global Terrorism Database (GTD) veri tabanından ulaşılmıştır. Modelde kullanılan iktisadi hoşnutsuzluk endeksi, enflasyon oranı ile işsizlik oranının toplamından oluşmaktadır. İktisadi hoşnutsuzluk endeksini elde etmek için kullanılan enflasyon oranı tüketici fiyatlarındaki yıllık yüzde değişim, işsizlik oranı işgücünün yıllık yüzdesi olarak alınmaktadır. Terör olaylarını temsil eden küresel terörizm endeksi ise 0 ile 10 değerleri arasında olup, 0 terör etkisinin olmadığını, 10 terörizmin en yüksek etkisini göstermektedir.

\section{Metodoloji ve Analiz Bulguları}

Çalışmada ilk olarak yatay kesit bağımlılık testi yapılımıştır. Panel veri analizlerinde yatay kesit bağımlılı̆ğ test edilirken kullanılan testler genel olarak Breusch-Pagan LM testi, Pesaran LM ${ }_{C D}$ testi ve Pesaran ve diğerleri $\mathrm{LM}_{\text {adj. }}$ testidir. N ülke sayısı, T zaman serisi olmak üzere; Breusch-Pagan LM testi, T'nin büyük N'nin küçük olduğu $(\mathrm{T}>\mathrm{N})$ durumda uygulanan bir yatay kesit bağımlılık testidir. Pesaran LM $_{\mathrm{CD}}$ testi, N'nin büyük T'nin küçük olduğu $(\mathrm{N}>\mathrm{T})$ durumda yatay kesit bağımlılığının olup olmadığını

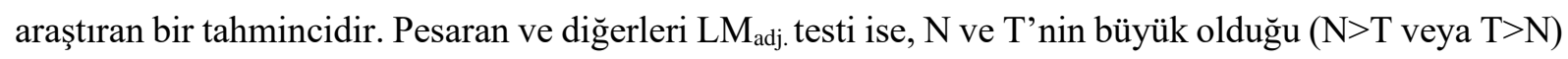
durumda uygulanan bir testtir (Yerdelen Tatoğlu, 2017: 237). Tablo 2'de yatay kesit bağımlılık test sonuçları sunulmuştur. 
Tablo 2: Yatay Kesit Bağımlılık Testi

\begin{tabular}{|l|l|l|}
\hline Test & Istatistik & Olasılık \\
\hline $\mathrm{LM}$ & 79.04 & 0.0000 \\
\hline $\mathrm{LM}_{\mathrm{adj}}$ & 10.75 & 0.0000 \\
\hline $\mathrm{LM}_{\mathrm{CD}}$ & 2.203 & 0.0276 \\
\hline
\end{tabular}

Tablo 2'de, LM ve LMadj testlerine göre, modele ait olas1l1k değerleri \%1'den küçük olduğu için modelde "yatay kesit bağımlılığı yoktur" şeklindeki $\mathrm{H}_{0}$ hipotezi reddedilerek modelde yatay kesit bağımlılığının olduğuna karar verilmiştir. Serilerde yatay kesit bağımlılığının olması, serilerin durağanlığının tespitinde birim kök testlerinden ikinci nesil birim kök testlerinin kullanılması gerektiğini göstermektedir. Bu kapsamda Pesaran CADF testi ile birim kök sınaması gerçekleştirilmiştir. Pesaran CADF testi, $\mathrm{T}>\mathrm{N}$ veya $\mathrm{N}>\mathrm{T}$ olmak üzere her iki durumda da kullanılmaktadır. Test istatistiği, Pesaran CADF kritik tablo değerleriyle karşılaştırılmaktadır. CADF istatistiği \%1, \%5, \%10 önem düzeyinde verilen kritik tablo değerinden büyükse serinin durağan olduğuna karar verilir (Yerdelen Tatoğlu, 2017: 87). CADF birim kök test sonuçları Tablo 3 'de yer almaktadır.

Tablo 3: CADF Birim Kök Testi

\begin{tabular}{|l|l|l|l|l|}
\hline Değişkenler (Düzey) & Test ist. & $\mathbf{\% 1}$ & $\mathbf{\% 5}$ & $\mathbf{\% 1 0}$ \\
\hline MI & -1.961 & -2.600 & -2.340 & -2.210 \\
\hline GTI & -1.472 & -2.600 & -2.340 & -2.210 \\
\hline Değişkenler (Birinci Fark) & Test ist. & $\mathbf{\% 1}$ & $\mathbf{\% 5}$ & $\mathbf{\% 1 0}$ \\
\hline MI & -2.857 & -2.600 & -2.340 & -2.210 \\
\hline GTI & -2.690 & -2.600 & -2.340 & -2.210 \\
\hline
\end{tabular}

Tablo 3'deki CADF birim kök test sonuçlarına göre, seriler birinci farklarında, I(1) düzeyinde durağandırlar. Serilerin tümü I(1) düzeyinde durağan olduğu için eşbütünleşme testi yapılabilir. Ancak onun öncesinde Swamy S testi ile homojenlik testi yapılarak eğim katsayılarının homojenliği belirlenmeye çalışılmıştır. Böylece elde edilen sonuçlara göre uygun eşbütünleşme ve nedensellik testlerine geçilebilmektedir. Swamy S homojenlik test sonuçları Tablo 4'deki gibidir.

Tablo 4: Swamy S Homojenlik Testi

\begin{tabular}{|l|l|}
\hline Test İstatistiği & Olasılık Değeri \\
\hline 173.54 & 0.0000 \\
\hline
\end{tabular}

Homojenlik test sonuçlarına göre, $\mathrm{H}_{0}$ hipotezi reddedilir ve panel heterojendir önermesi kabul edilir. Diğer bir ifadeyle seriler \% 1 anlamlllı düzeyinde heterojendir. Bu durumda uygun eşbütünleşme testi ve tahmin yöntemi seçilmelidir ki, seriler arasında eşbütünleşme ilişkisinin olup olmadığı ile eşbütünleşme modelinin tahmininde yatay kesit bağımlılığı ile heterojenliği göz önünde bulunduran ikinci nesil panel eşbütünleşme analizi yöntemleri kullanılmıştır. Tablo 5'de Westerlund (2007) bootstrap panel eşbütünleşme test sonuçları yer almaktadır.

Tablo 5: Westerlund Bootstrap Panel Eşbütünleşme Testi

\begin{tabular}{|l|l|l|l|l|}
\hline Test & $\mathbf{t}_{\text {test }}$ & $\mathbf{Z}_{\text {test }}$ & Olasılık & Robust-Olasılık \\
\hline $\mathrm{Gt}$ & -3.313 & -5.129 & 0.000 & 0.040 \\
\hline $\mathrm{Ga}$ & -12.574 & -2.974 & 0.002 & 0.110 \\
\hline $\mathrm{Pt}$ & -13.310 & -8.772 & 0.000 & 0.030 \\
\hline
\end{tabular}




\section{Rabia EFEOĞLU}

İktisadi Hoşnutsuzluk Endeksi ve Terörizm Arasındaki İlişki: Türkiye ve Avrasya Ülkeleri Örneği

\begin{tabular}{|l|l|l|l|l|}
\hline $\mathrm{Pa}$ & -17.590 & -8.653 & 0.000 & 0.050 \\
\hline
\end{tabular}

Westerlund bootstrap panel eşbütünleşme testi hem grup hem de bütün paneli dikkate alan ve serilerin homojen veya heterojen olma durumlarına göre uygulanabilen bir testtir. Panelin heterojen olması durumunda Ga ve Gt değerleri, homojen olması durumunda $\mathrm{Pa}$ ve Pt değerleri dikkate alınmaktadır. Tablo 5'de, Westerlund (2007) eşbütünleşme testinde modelde yatay kesit bağımlılığ olduğu için bootstrap olasılık değeri dikkate alınmıştır. Panel heterojen olduğundan Ga ve Gt istatistiklerine göre yorum yapılması doğru olacaktır. Westerlund (2007) bootstrap panel eşbütünleşme testi sonuçlarından Gt istatistiğine göre eşbütünleşme ilişkisi varken, Ga istatisiğine göre yoktur. Test istatistiklerine göre $\mathrm{H}_{0}$ hipotezi reddedilerek, iktisadi hoşnutsuzluk endeksi ile terör olayları arasında eşbütünleşme ilişkisinin olduğu bulgusu elde edilmiştir.

Değişkenler arasında eşbütünleşme ilişkisi olduğundan eşbütünleşme modeli tahmin edilebilir. Çalışmada yatay kesit bağımlılığı ve heterojenliğin olması sebebiyle uzun dönem eşbütünleşme katsayıları DOLSMG (Ortalama Grup Dinamik En Küçük Kareler) tahmincisi ile yapılmaktadır (Yerdelen, Tatoğlu, 2017: 233). Tablo 6'da uzun dönem eşbütünleşme katsayıları sunulmaktadır.

Tablo 6: DOLSMG Tahmincisi

\begin{tabular}{|l|l|l|}
\hline Ülke & GTI & t- istatistiği \\
\hline Ermenistan & -8.879 & $-2.896^{* * *}$ \\
\hline Azerbaycan & 4.037 & 1.576 \\
\hline Belarus & 6.992 & $2.46^{* *}$ \\
\hline Gürcistan & 1.094 & $2.282^{* *}$ \\
\hline Kırgizistan & -2.707 & $-2.856^{* * *}$ \\
\hline Moldova & -0.1028 & -0.083 \\
\hline Rusya & 3.066 & $3.785^{* * *}$ \\
\hline Ukrayna & 1.409 & 1.613 \\
\hline Türkiye & 3.515 & $5.055^{* * *}$ \\
\hline Panel & 0.9361 & $3.645^{* * *}$ \\
\hline
\end{tabular}

Not: ${ }^{* * *, * *}, *$ sirasıyla $\% 1, \% 5$ ve $\% 10$ seviyesinde anlamlllık düzeyleridir.

Tablo 6'da panelin geneline bakıldığında, terörizm ve iktisadi hoşnutsuzluk endeksi arasında pozitif ve istatistiksel olarak anlamlı bir ilişki vardır. Küresel terörizm endeksindeki 1 birim artış iktisadi hoşnutsuzluk endeksini 0.94 birim artırmaktadır. Diğer bir ifadeyle terör olaylarındaki artış iktisadi hoşnutsuzluğu artırmaktadır. Terörizm ve iktisadi hoşnutsuzluk endeksi arasındaki ilişkiye ülkeler açısından bakıldığında; Azerbaycan, Belarus, Gürcistan, Rusya, Ukrayna ve Türkiye'de terörün iktisadi hoşnutsuzluk endeksi üzerindeki etkisi pozitif ancak Azerbaycan ve Ukrayna'da istatistiksel olarak anlamsız bir ilişki bulunmuştur. Yani Belarus, Gürcistan, Rusya ve Türkiye'de terör olaylarındaki artışlar iktisadi hoşnutsuzluğu artırmakta; Azerbaycan ve Ukrayna'da ise terör olaylarındaki artışlar iktisadi hoşnutsuzluğu etkilememektedir. Diğer taraftan Ermenistan, Kırgızistan ve Moldova'da negatif ve Moldova'da istatistiksel olarak anlamsız bir ilişki bulunmuştur. Yani Ermenistan ve Kırgızistan'da 
terör olaylarındaki artışlar iktisadi hoşnutsuzluğu azaltmakta; Moldova'da ise terör olayları iktisadi hoşnutsuzluğu etkilememektedir.

Çalışmada, Dumitrescu ve Hurlin (2012) panel nedensellik testiyle seriler arasındaki nedensellik ilişkisi araştırılmıştır. Dumitrescu-Hurlin panel nedensellik testi hem yatay kesit bağımlılığını hem de heterojenliği dikkate alan ve zaman boyutunun $(\mathrm{T})$ kesit boyutundan $(\mathrm{N})$ büyük veya küçük olduğu durumlarda kullanılan bir testtir. Değişkenler arasında eşbütünleşme ilişkisi çıktığından DumitrescuHurlin panel nedensellik testi ile nedensellik analizi yapılmış ve Tablo 7'de sonuçlar sunulmuştur.

Tablo 7: Dumitrescu-Hurlin Panel Nedensellik Testi

\begin{tabular}{|l|l|l|l|}
\hline Nedensellik Yönü & $\mathbf{Z}$ istatistiği & Olasılık & Karar \\
\hline GTI $\rightarrow$ MI & 2.2026 & 0.0276 & Nedensellik Var \\
\hline MI $\rightarrow$ GTI & 1.3712 & 0.1703 & Nedensellik Yok \\
\hline
\end{tabular}

Dumitrescu-Hurlin panel nedensellik test sonuçlarına göre, terörizmden iktisadi hoşnutsuzluk endeksine doğru tek yönlü bir nedensellik ilişkisinin olduğu görülmüştür. Böyle bir ilişkinin tespit edilmesi, Türkiye ve Avrasya ülkelerinde ilgili dönemdeki terörizmin iktisadi hoşnutsuzluğu etkilediği sonucunu göstermektedir.

\section{Sonuç}

Ülke ekonomilerinin değerlendirilmesinde makroekonomik performans göstergeleri önemli olmakla birlikte sosyal değişimlerin de ekonomi üzerinde önemli etkilerinin olduğu dikkate alınmalıdır. Bu kapsamda toplumlar üzerinde ekonomik, sosyal, siyasal ve psikolojik sonuçlar doğuran sosyal bir gösterge olan terörizmin iktisadi hoşnutsuzluk ile ilişkisi incelenmiştir. Türkiye ve Avrasya ülkelerinde terörizm ve iktisadi hoşnutsuzluk ilişkisinin araştırıldığg çalışmada 2002-2018 dönemi ele alınarak panel veri analiz yöntemi kullanılmıştır. Elde edilen bulgular şu şekildedir: Ülkelerin iktisadi hoşnutsuzluk endeksi ve küresel terörizm endeksi ile oluşturulan modelin bütününde yatay kesit bağımlılığ 1 vardır. Serilerde birim kökün varlığı, yatay kesit bağımlılı̆̆ını dikkate alan CADF testiyle analiz edilmiş, serilerin düzeyde durağan olmadıkları ve birinci farklarında durağanlaştıkları görülmüştür. Serilerin birinci farkında durağanlaşması eşbütünleşme ilişkisinin aranması gerektiğini göstermiştir. Ancak öncesinde Swamy S homojenlik testi yapılarak ikinci nesil eşbütünleşme testi yapılmasına karar verilmiştir. Seriler arasındaki eşbütünleşme ilişkisinin varlığı, Westerlund (2007) bootstrap panel eşbütünleşme testiyle incelenmiş ve seriler arasında eşbütünleşme ilişkisinin olduğu görülmüştür. Uzun dönem eşbütünleşme katsayıları, yatay kesit bağımlılığı ve heterojenliği dikkate alan DOLSMG yöntemiyle tahmin edilmiştir. Elde edilen sonuçlara göre, panelin genelinde terörizm ve iktisadi hoşnutsuzluk endeksi arasında pozitif ve istatistiksel olarak anlamlı bir ilişki vardır. Türkiye ve Avrasya ülkelerinde terör olaylarındaki artışlar iktisadi hoşnutsuzluğu artırmaktadır. Ülkeler açısından bakıldığında ise, Azerbaycan, Ukrayna ve Moldova ülkelerinde terörizmin iktisadi hoşnutsuzluk üzerinde istatistiksel olarak anlamlı bir etkisi yok iken, diğer ülkelerde istatistiksel olarak anlamlı bir etkiye sahiptir. Anlamlı etkiye sahip olan ülkelerden Ermenistan ve Kırgızistan dışındaki ülkelerde terör olaylarındaki artış iktisadi hoşnutsuzluğu artırmaktadır. Ermenistan ve Kırgızistan'da ise terör 


\section{Rabia EFEOĞLU}

İktisadi Hoşnutsuzluk Endeksi ve Terörizm Arasındaki İlişki: Türkiye ve Avrasya Ülkeleri Örneği

olaylarının iktisadi hoşnutsuzluğu negatif yönde etkilemesi yani azaltması, söz konusu ülkelerdeki terör olayları ve yıkıcı etkileri, ülkelerin terörle mücadele politikalarındaki tutumu ve ülkelerin makroekonomik gelişme düzeyi ile ilgili olduğu düşünülmektedir. Seriler arasında eşbütünleşme ilişkisi bulunduktan sonra Dumitrescu ve Hurlin (2012) nedensellik testi ile gerçekleştirilen nedensellik analizinde terörizmden iktisadi hoşnutsuzluk endeksine doğru tek yönlü nedensellik ilişki bulunmuştur. Türkiye ve Avrasya ülkelerinde terör olayları iktisadi hoşnutsuzluğun nedenidir.

Sonuç olarak; ekonomik, sosyal, kültürel ve ekonomik olarak ulusal ve uluslararası bir sorun haline gelen terörizm arttıkça ülkelerin iktisadi hoşnutsuzluğu artış göstermektedir. Ülkelerde terör olaylarını önleyebilmek için yeterli rezerv olmaması emisyon hacmini artırmakta, enflasyon düzeyinin dolayısıyla da iktisadi hoşnutsuzluğun arttığı bir sürece girilmektedir. Böylece terör olaylarına bağlı olarak iktisadi hoşnutsuzluk endeksindeki artış makroekonomik istikrarsızlığına yol açmaktadır. $\mathrm{Bu}$ bağlamda, terör olaylarının enflasyon düzeyini yükseltmesi, dolayısıyla da iktisadi hoşnutsuzluğu artırıcı yönde bir olgunun ortaya çıktı̆̆ı ifade edilebilir.

Bütün bunlardan hareketle, politika önerisi olarak; politika yapıcıları terörle mücadele politikaları oluşturarak söz konusu ülkelerdeki iktisadi hoşnutsuzluğu azaltabilirler. Ayrıca ülkelerde terör olaylarının hızını yavaşlatıcı ekonomik, sosyal ve politik tedbirlerin ivedilikle alınması ve uygulanması, ülkelerin kurumsal gelişimini sağlayan ekonomik politika önlemlerinin alınmasının yanı sıra yüksek enflasyon oranlarının düşürülmesi ve istihdam olanaklarının artırılması gerekir ki, böylece söz konusu ülkelerde terörizmin sebep olduğu iktisadi hoşnutsuzluk artışının önüne geçilebilir. Özellikle terör olayları ve iktisadi hoşnutsuzluk özelinde incelenen çalışmada bir öneri de, daha sonra yapılacak çalışmalarda terörün farklı makroekonomik göstergelere etkisinin ya da iktisadi hoşnutsuzluğu etkileyen başka sosyal hoşnutsuzluk göstergeleri kullanılarak farklı örneklem büyüklükleri ile çalışılabileceğidir.

\section{Kaynakça}

Beşkaya, A. (2013). Political economy of economic discomfort: A time series analysis of Turkey, 19802010. Ekonomik ve Sosyal Araştırmalar Dergisi, 9(1), 1-14.

Çağlayan Akay, E. ve Oskonbaeva, Z. (2020). İktisadi büyüme ve sefalet endeksi arasındaki ilişki: Geçiş ülkeleri örneği. International Conference on Eurasian Economies 2020.

Çondur, F. (2016). Türkiye'de hoşnutsuzluk endeksi parametrelerinin gelişimi. Atatürk Üniversitesi İktisadi ve İdari Bilimler Dergisi, 30(5), 1309-1327.

Dadgar, Y. ve Nazari, N. (2012). The impact of economic growth and good governance on misery index in Iranian economy. European Journal of Law and Economics, 45(1), 175-193. DOI 10.1007/s10657-012-9327-2.

Grabia, T. (2012). The Okun misery index in the European Union countries from 2000 to 2009. Comparative Economics Research, 14(4), 97-115. https://doi.org/10.2478/v10103-011-00298.

Institute for Economics and Peace (2021). https://www.visionofhumanity.org/public-release-data/

Korkmaz, Ö. (2018). Terörizm ve makroekonomi: Avrasya ülkeleri üzerine bir inceleme. International Journal of Economics Politics Humanities and Social Sciences, 1(2), 75-85. 
Lechman, E. (2009). Okun's and Barro's misery index as an alternative poverty assessment tool. Recent estimations for European countries. MPRA Paper, 37493, 1-10.

Lee, S., Cheong, K. ve Suh, S. H. (2007). International comparison of economic performance index: The case of the USA, Japan and Korea. The American Economist, 51(1), 63-74.

Oskay, C. (2018). Küresel kriz sonrası kırılgan beşli ülkelerin makroekonomik performansları üzerine karşılaştırmalı bir analiz. H. Sağlam ve M. E. Kenanoğlu (Ed.), ICOPEC 2018: 10 years after the great recession: orthodox versus heterodox economics 9. international conference on political economy, abstracts \& proceeding book kitabı içinde (s. 47-55). London: IJOPEC Publication.

Özcan, S. E. (2016). Yoksulluk göstergesi olarak hoşnutsuzluk endeksi, Türkiye için bir deneme. Dumlupınar Üniversitesi Sosyal Bilimler Dergisi, 48, 294-313.

Özdemir, A. ve Salihoğlu, M. (2019). Ekonomik ve politik faktörlerin insani gelişmişlik üzerindeki etkileri. Uluslararası Ekonomik Araştırmalar Dergisi, 5(3), 21-35.

Saboor, A., Sadiq, S., Khan, A. U. ve Hameed, G. (2016). Dynamic reflections of crimes, quasi democracy and misery index in Pakistan. Social Indicators Research, 133, 31-45. DOI 10.1007/s11205-016-1348-8.

Sadeghi, S. K., Marvasti, M. B. ve Karbor, R. (2014). New evidence on the link between income inequality and misery index: A nonlinear time series analysis. International Journal of Sustainable Development \& World Policy, 3(1), 25-30.

Tatoğlu Yerdelen, F. (2018). İleri panel veri analizi stata uygulamalı. İstanbul: Beta Yayımcılık.

Taşcı, K. ve Özsan, M. E. (2011). Bölgesel hoşnutsuzluk endeksi. 12. Uluslararası Ekonometri, Yöneylem Araştırması ve İstatistik Sempozyumu, 26-29 Mayıs 2011, Pamukkale Üniversitesi, Denizli.

Ülgen, G. ve Özer, M. O. (2020). İktisadi hoşnutsuzluk endeksi ile cari açık arasındaki ilişkinin ampirik analizi: Türkiye örneği. Akademik İncelemeler Dergisi, 15(1), 83-112.

Wang, N., Shah, M. H., Ali, K., Abbas, S. ve Ullah, S. (2019). Financial structure, misery index, and economic growth: time series empirics from Pakistan. Journal of Risk and Financial Management, 12(100), 1-15. doi:10.3390/jrfm12020100.

Welsch, H. (2007). Macroeconomics and life satisfaction: Revisiting the "misery index". Journal of Applied Economics, 10(2), 237-251.

Worldbank (2021). https://www.worldbank.org/ 